\title{
Ondersoek na die gebruik van ortogonale ontbinding om interne okulêre druk te bepaal
}

\begin{tabular}{|c|c|}
\hline $\begin{array}{l}\text { Authors: } \\
\text { Natasha Both } \\
\text { Schalk Kok }{ }^{1} \\
\text { Helen Inglis }\end{array}$ & \\
\hline $\begin{array}{l}\text { Affiliations: } \\
{ }^{1} \text { Advanced Ma } \\
\text { Modelling and } \\
\text { Sciences, CSIR }\end{array}$ & $\begin{array}{l}\text { thematical } \\
\text { Digital }\end{array}$ \\
\hline $\begin{array}{l}{ }^{2} \text { Department } \\
\text { and Aeronauti } \\
\text { Engineering, } \\
\text { Pretoria, Sout }\end{array}$ & $\begin{array}{l}\text { f Mechanical } \\
\text { cal } \\
\text { Iniversity of } \\
\text { Africa }\end{array}$ \\
\hline $\begin{array}{l}\text { Corresponden } \\
\text { Natasha Botha }\end{array}$ & ce to: \\
\hline $\begin{array}{l}\text { Email: } \\
\text { nbotha1@csir. }\end{array}$ & co.za \\
\hline $\begin{array}{l}\text { Postal address } \\
\text { Private Bag X2 } \\
\text { Pretoria } 0028 \text {, }\end{array}$ & $\begin{array}{l}\text { 0, Hatfield, } \\
\text { South Africa }\end{array}$ \\
\hline $\begin{array}{l}\text { How to cite th } \\
\text { Botha, N., Kok } \\
\text { H., 2013, 'Ond } \\
\text { die gebruik va } \\
\text { ontbinding om } \\
\text { okulêre druk t } \\
\text { Suid-Afrikaans } \\
\text { vir Natuurwet } \\
\text { Tegnologie } 32 \\
\text { \#406, } 1 \text { page. } \\
\text { org/10.4102/s }\end{array}$ & $\begin{array}{l}\text { is abstract: } \\
\text {, S. \& Inglis, } \\
\text { ersoek na } \\
\text { n ortogonale } \\
\text { interne } \\
\text { e bepaal', } \\
\text { e Tydskrif } \\
\text { enskap en } \\
\text { (1), Art. } \\
\text { http://dx.doi. } \\
\text { atnt.v32i1.406 }\end{array}$ \\
\hline $\begin{array}{l}\text { Note: } \\
\text { This abstract } \\
\text { at the 'Studen } \\
\text { in die Natuurn } \\
2011 \text { ', present } \\
\text { the protection } \\
\text { Afrikaanse Akc } \\
\text { Wetenskap en } \\
\text { symposium wa } \\
\text { University of S } \\
27-28 \text { Octobe }\end{array}$ & $\begin{array}{l}\text { vas presented } \\
\text { tesimposium } \\
\text { vetenskappe } \\
\text { ed under } \\
\text { of the Suid- } \\
\text { ademie vir } \\
\text { Kuns. The } \\
\text { as held at the } \\
\text { outh Africa on } \\
\text { r } 2011 \text {. }\end{array}$ \\
\hline $\begin{array}{l}\text { Copyright: } \\
\text { (C) 2013. The A } \\
\text { Licensee: AOSI } \\
\text { OpenJournals. } \\
\text { is licensed und } \\
\text { Creative Comn } \\
\text { Attribution Lic }\end{array}$ & $\begin{array}{l}\text { IS } \\
\text { IS } \\
\text { This work. } \\
\text { ler the } \\
\text { nons } \\
\text { ense. }\end{array}$ \\
\hline Read online: & \\
\hline 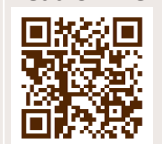 & $\begin{array}{l}\text { Scan this QR } \\
\text { code with your } \\
\text { smart phone or } \\
\text { mobile device } \\
\text { to read online. }\end{array}$ \\
\hline
\end{tabular}

Investigating the use of proper orthogonal decomposition to determine intra-ocular pressure. Accurately determining intraocular pressure (IOP) is crucial to the diagnosis and management of glaucoma, the leading cause of irreversible blindness in South Africa. This study aims to investigate the possibility of using proper orthogonal decomposition (POD) to determine IOP from ocular response data obtained from numerical simulations.

Gloukoom, 'n oogsiekte wat die optiese senuwee permanent beskadig, is die tweede grootste oorsaak van blindheid (naas katarakte, wat behandelbaar is), en die primêre oorsaak van permanente blindheid in Suid-Afrika. Verhoogde interne okulêre druk (IOD) is die belangrikste risikofaktor vir die ontwikkeling van gloukoom, en moet dus met akkuraatheid bepaal word om gloukoom, wat kronies behandel kan word, betyds te diagnoseer. Hierdie studie beoog om te bepaal of die numeriese tegniek bekend as POD (ortogonale ontbinding - in Engels 'proper orthogonal decomposition') gebruik kan word om die IOD meer akkuraat te bepaal. Die werk van Ghaboussi et al. (2009) is uitgebrei in hierdie studie, waarin 'n kombinasie van kunsmatige neurale netwerke en genetiese algoritmes gebruik is om die IOD te bepaal. Die IOD word met behulp van kontak- en nie-kontak tonometrie bepaal. Hierdie tegnieke, wat daarop berus om die indentasieweerstand van die kornea te gemeet, toon 'n mate van onakkuraatheid weens die kalibrasie van die meetinstrumente wat gebruik word om die die kornea-eienskappe van die gemiddelde populasie te bepaal. Pasiënte wat beduidend verskillende kornea-eienskappe openbaar, se werklike IOD word gevolglik onakkuraat geskat.

'n Numeriese simulasie van die kornea gedurende kontak is opgestel deur van die eindigeelementmetode gebruik te maak. Die kontaksimulasie verteenwoordig die algemeenste toets vir gloukoom, naamlik Goldmann se verplattingstonometrie. Gedurende die toets word 'n glasskyfie teen die kornea gedruk, en word die krag gemeet waar die kontakarea-deursnit $3.06 \mathrm{~mm}$ is. Hierdie krag word met behulp van 'n kalibrasiekonstante na 'n IOD-lesing oorgeskakel. In hierdie studie word die aanname gemaak dat die Goldmann-toestel verander kan word om nie net ' $n$ enkele kraglesing te neem nie, maar om die hele krag-verplasingsgeskiedenis beskikbaar te stel. Die numeriese simulasie word gebruik om die krag-verplasingsgeskiedenis vir verskeie kombinasies kornea-eienskappe te bepaal. Die krag-verplasingsgeskiedenis word dan as inset vir die POD-algoritme gebruik om 'n stel modusse te bereken. Die modusse, wat funksies van die kornea-eienskappe is, word gebruik om 'n verwantskap tussen die kragverplasingsgeskiedenis en die ooreenstemmende kornea-eienskappe te definieer. Dit word met behulp van die kleinstekwadrate-metode gedoen. Die IOD en kornea-eienskappe word bepaal deur middel van 'n inverse proses waarby 'n onbekende krag-verplasingsgeskiedenis vir die algoritme as inset gegee word. Die algoritme gebruik die verwantskap tussen krag-verplasing en kornea-eienskappe om die IOD asook die kornea-eienskappe as uitset te gee. Die akkuraatheid van die POD-metode word geillustreer deur aan te toon dat die IOD nou minder afhanklik van die kornea-eienskappe is. Die metode word ook op 'n bekende kliniese geval toegepas om beter uitkomste te kwantifiseer.

Die resultate toon dat die POD-metode wel gebruik kan word om 'n betreklik akkurate bepaling van die IOD te kry, onafhanklik van die materiaaleienskappe. Die IOD wat volgens hierdie metode bepaal word, stem redelik ooreen met dié van 'n kombinasie van die kunsmatige neurale netwerk en genetiese algoritmes. Die POD-metode toon potensiaal as 'n effektiewe manier om die IOD te bepaal.

\section{Literatuurverwysing}

Ghaboussi, J., Kwon, T.H., Pecknold, D. \& Hashash, Y., 2009, 'Accurate intraocular pressure prediction from applanation response data using genetic algorithm and neural networks', Journal of Biomechanics 42, 2301-2306. 